\title{
PHYSICOCHEMICAL PARAMETERS AS INDICATORS OF THE AUTHENTICITY OF MONOFLORAL HONEY FROM THE TERRITORY OF THE REPUBLIC OF SERBIA
}

\author{
Saša Milosavljević1, Milka Jadranin ${ }^{2}$, Mića Mladenović ${ }^{3}$, Vele Tešević ${ }^{4}$, Nebojša Menković ${ }^{5}$, \\ Dragosav Mutavdžićc , Gordana Krstićc ${ }^{*}$ \\ ${ }^{1}$ College of Agriculture and Food Technology, Prokuplje, Cirila i Metodija 1, 18400 Prokuplje, Serbia \\ ${ }^{2}$ University of Belgrade - Institute of Chemistry, Technology and Metallurgy, Department of Chemistry, \\ Njegoševa 12, 11000 Belgrade, Serbia \\ ${ }^{3}$ Faculty of Agriculture, University of Belgrade, Nemanjina 6, 11080 Zemun, Serbia \\ ${ }^{4}$ University of Belgrade - Faculty of Chemistry, Studentski trg 12-16, 11000 Belgrade, Serbia \\ ${ }^{5}$ Institute for Medicinal Plant Research "Dr Josif Pančić”, Tadeuša Košćuška 1, Belgrade, Serbia \\ ${ }^{6}$ University of Belgrade - Institute for Multidisciplinary Research, Kneza Višeslava 1, \\ 11030 Belgrade, Serbia \\ gkrstic@chem.bg.ac.rs
}

\begin{abstract}
The aim of this research was to verify the authenticity of monofloral honeys from the territory of the Republic of Serbia on the basis of physicochemical parameters routinely measured in honey quality control using multivariate analysis. Seventeen samples of monofloral honey (11 samples of acacia honey and 6 samples of sunflower honey) from the territory of the Republic of Serbia were analyzed. Physicochemical analysis of the samples included the examination of basic quality parameters and qualitative and quantitative analyses of phenolic compounds. In the samples tested, a total of 93 phenolic compounds were tentatively identified, and 19 of them were quantified. The obtained physicochemical analysis of the data served as input for the multivariate analysis. The heat map, which is useful for visualizing numerical data, was used for this purpose. The obtained results showed that the applied data can serve to clearly separate acacia and sunflower honeys.
\end{abstract}

Keywords: monofloral honey; total phenols; physicochemical analysis; multivariate analysis

\section{ФИЗИКОХЕМИСКИ ПАРАМЕТРИ КАКО ИНДИКАТОРИ НА АВТЕНТИЧНОСТА НА МОНОЦВЕТЕН МЕД ОД ТЕРИТОРИЈАТА НА РЕПУБЛИКА СРБИЈА}

Целта на ова истражување беше да се потврди автентичноста на моноцветен мед од територијата на Република Србија врз основа на физикохемиските параметри што рутински се мерат при контрола на квалитетот на медот со примена на мултиваријантната анализа. Беа анализирани 17 примероци моноцветен мед (11 примероци мед од акација и 6 примероци мед од сончоглед) од територијата на Република Србија. Физикохемиските анализи на примероците вклучуваа испитување на основните параметри за квалитет, како и квалитативна и квантитативна анализа на фенолните соединенија. Во примероците што беа тестирани, хипотетички беа идентификувани вкупно 93 фенолни соединенија, а 19 од нив беа и квантификувани. Добиените податоци од физикохемиската анализа беа употребени како влезни податоци за мултиваријантна анализа. Беше применета топлинска мапа која е корисна за визуализација на нумеричките податоци. Добиените резултати покажуваат дека применетите податоци можат да послужат за јасно да се одвои медот од акација од медот од сончоглед.

Клучни зборови: моноцветен мед; вкупни феноли; физикохемиска анализа; мултиваријантна анализа 


\section{INTRODUCTION}

Honey is the natural sweet substance produced by Apis mellifera bees from the nectar of plants, from secretions of living parts of plants, or from the excretions of plant-sucking insects on the living parts of plants, which the bees collect, transform by combining with specific substances of their own, deposit, dehydrate, store, and leave in honeycombs to ripen and mature [1]. Honey is composed of sugars and other organic (amino acids, proteins, carotenoids, vitamins, flavonoids, and other phenolic compounds) and inorganic (macroelement and microelement minerals, such as potassium, magnesium, calcium, iron, phosphorus, sodium, manganese, iodine, zinc, lithium, cobalt, nickel, cadmium, copper, barium, chromium, selenium, arsenic and silver) substances [2, 3].

Depending on the number of plant species from which honey is obtained, all types of honey can be divided into two basic groups: monofloral and polyfloral. Polyfloral honey is mixed honey that comes from various species of plants and is often referred to as herbal or wildflower honey. Monofloral honey originates from the nectar of one plant species, such as sunflower, acacia, linden, etc. [4]. In Europe, there are over 100 plant species that are known to provide monofloral honey, but only a few of them are of commercial importance [5].

According to Council Regulation 2014/63/EU from May 15, 2014, relating to honey, the main ingredients of honey are the monosaccharides fructose and glucose (at least $60 \%$ total), disaccharide sucrose (5-10\%), and water (up to $20 \%$ ). The content of free acids in honey should be a maximum of 50 $\mathrm{mEq}$ acid/100 $\mathrm{g}$ of honey, with an electrical conductivity maximum of $0.8 \mathrm{mS} / \mathrm{cm}$, a diastase activity (according to Schade) of at least 8, and a hydroxymethylfurfural (HMF) maximum of $40 \mathrm{mg} / \mathrm{kg}$ $[1,6]$. The color, aroma and consistency of honey depend on the plants from which the bees collect the nectar. Honey also contains a wide range of other substances at lower concentrations. These include a variety of phenolic acids, flavonoids, amino acids, enzymes, proteins, etc. Differences in the physical and chemical composition of the same type of honey depend on many factors, such as agroecological environmental conditions, the presence of pollen in honey, meteorological factors, applied apitechnics, processing, storage of honey, etc. $[4,5]$.

Pollen, propolis and wax are the main sources of phenolic compounds in honey [7, 8]. The phenolic compounds present in honey can be classified into two groups: simple phenols and polyphenols. Simple phenols in honey comprise different phenolic acids, while the most common pol- yphenols are various flavonoids and flavones [9, 10]. Phenolic acids and polyphenols are plantderived secondary metabolites. These compounds have been used as chemotaxonomic markers in plant systematics. Some of them have also been proposed as possible markers for the determination of the botanical origin of honey [11-15].

Defining discriminatory factors for monofloral honey is problematic as bees generally collect nectar from several plant species; although, one species may be dominant, and, therefore, there are no references to absolutely pure monofloral honey. Therefore, this study aimed to investigate whether the physicochemical parameters measured to control the quality of honey could be used as input data for multivariate analysis, which would separate and group sunflower and acacia honey. The results obtained in this study should enable the quick and easy verification of the authenticity of honey.

\section{EXPERIMENTAL SECTION}

\subsection{Honey samples}

Honey samples were collected in 2010 in Serbia towards the end of the nectar collecting period. The dominant honey species in this territory are acacia and sunflower.

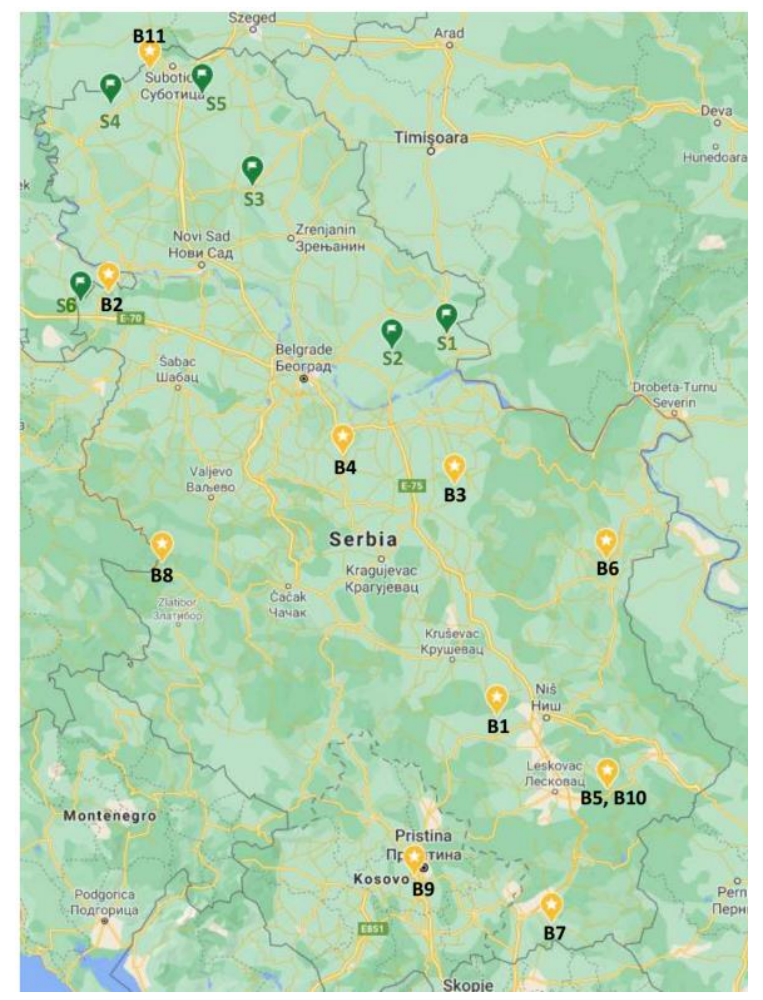

Fig. 1. Places in the Republic of Serbia where samples were collected (B1, Devča; B2, Lipovača; B3, Dobrnje; B4, Banja Selters; B5, B10, Veliko Bonjince; B6, Rgotina; B7, Bustranje; B8, Crvica; B9, Ugljare; B11, Ljutovo; S1, Straža; S2, Mramorak; S3, Novi Bečej; S4, Aleksa Šantić; S5, Orom; S6, Ilinci). 
Honey samples were collected at 17 localities (Fig. 1), and 17 samples of honey were obtained (11 samples of acacia honey and 6 samples of sunflower honey). The selected regions are characterized by abundant vegetation cover of the above-mentioned plants.

\subsection{Physicochemical analysis}

Primary analyses were performed to verify the suitability of the obtained samples, and thus be used as primary guidance in the identification and classification of the botanical origin of honey. The honey samples were analyzed for reducing sugars, sucrose, water, water-insoluble substances, free acids, HMF, minerals, and electrical conductivity, according to the Harmonized European Commission methods for honey $[6,16]$. Diastasis activity was analyzed by AOAC method 958.09 [17].

\subsubsection{Determination of water content}

The water content in the honey was determined by measuring the refractive index using an Abbe refractometer (Atago ${ }^{\circledR} 1 \mathrm{~T}$ Abbe refractometer, Tokyo, Japan) at $20.0^{\circ} \mathrm{C}$. Water content was calculated by correlating the obtained refractive index values with the water values in the Chataway table [6].

\subsubsection{Determination of electrical conductivity}

The electrical conductivity in the honey was determined by measuring the electrical conductivity using a WTW Cond 330i with conductivity cell (WTW TetraCon325) at $20{ }^{\circ} \mathrm{C}$. The conductivity cell was calibrated with $0.01 \mathrm{M} \mathrm{KCl}$ solution (1413 $\mathrm{Ms} / \mathrm{cm}$, the cell constant was $0.481 / \mathrm{cm})$. A sample quantity equivalent to $20.0 \mathrm{~g}$ of anhydrous honey was dissolved in distilled water. The prepared solution was quantitatively transferred to a $100 \mathrm{ml}$ volumetric flask and filled to the volume with distilled water. A $40 \mathrm{ml}$ aliquot of the sample solution was transferred to a beaker and thermostated in a water bath at $20^{\circ} \mathrm{C}$. Then, the electrical conductivity was measured $[6,16]$.

\subsubsection{Determination of free acid content}

The sample was titrated in the presence of phenolphthalein with a solution of $0.1 \mathrm{~mol} / \mathrm{l}$ sodium hydroxide until a light pink color appeared. The free acid content, expressed in $\mathrm{mEq}$ of acid/ $\mathrm{kg}$ of honey, was calculated using the following formula $[6,16]$ :

Free Acid Content $(\mathrm{mEq} / \mathrm{kg})=\mathrm{ml} 0.1 \mathrm{~mol} / \mathrm{l} \mathrm{NaOH} \times 10$

\subsubsection{Determination of mineral content}

A sample weight of $0.6-0.7 \mathrm{~g}$ was transferred to a polytetrafluoroethylene (PTFE) cuvette for microwave digestion. One milliliter of $30 \%$ hydrogen peroxide and $7 \mathrm{ml}$ of $65 \%$ nitric acid were added. The sample was mineralized in an Ethos 1 microwave oven (Advanced Microwave Digestion System; Milestone, Italy). Upon completion of the digestion, the sample was cooled, transferred to a $50 \mathrm{ml}$ volumetric flask, and filled to the volume with bidistilled water. The content of the elements ( $\mathrm{Al}, \mathrm{Ag}, \mathrm{B}, \mathrm{Bi}, \mathrm{Ba}, \mathrm{Ca}, \mathrm{Cd}, \mathrm{Cr}, \mathrm{Co}, \mathrm{Cu}$, $\mathrm{Fe}, \mathrm{Ga}, \mathrm{In}, \mathrm{K}, \mathrm{Li}, \mathrm{Mg}, \mathrm{Mn}, \mathrm{Mo}, \mathrm{Na}, \mathrm{Ni}, \mathrm{Pb}, \mathrm{Sr}, \mathrm{Ti}$, and $\mathrm{Zn}$ ) was determined with a Thermo Scientific iCAP 6500 Duo ICP instrument (Thermo Fisher Scientific, Cambridge, UK). MultiElement Plasma Standard Solution 4, Specpure, $1 \mathrm{~g} / \mathrm{l}$, was used as the reference standard for all elements. The results obtained for the individual elements were collected and expressed as the percentage of minerals per $\mathrm{kg}$ of honey $[6,16]$.

\subsubsection{Determination of the content of reducing sugars}

The principle of this method is based on the reduction of Fehling's solution by titration with a solution of reduced sugars of honey using methylene blue as an indicator $[6,16]$.

\subsubsection{Determination of sucrose content}

This method is based on sucrose hydrolysis and the reduction of Fehling's solution by titration with reduced sugars from the hydrolysate of honey with methylene blue. The sucrose content is calculated as the difference between the amount of invert sugar after and before hydrolysis, and the difference obtained is multiplied by a factor of $0.95[6,16]$.

\subsubsection{Determination of insoluble substances content in water by the gravimetric method}

Twenty grams of the sample (to the nearest $\pm 10 \mathrm{mg}$ ) was weighed and dissolved in a specified amount of distilled water at $80{ }^{\circ} \mathrm{C}$, and the solution was mixed well. Then, the solution was filtered through a dried and measured sintered funnel with a pore size of $15-40 \mathrm{~mm}$. The sediment was washed with boiling water $\left(80^{\circ} \mathrm{C}\right)$ to release sugar, which was determined by the Mohr test. The funnel was dried at $135^{\circ} \mathrm{C}$ (drying time $1 \mathrm{~h}$ ), cooled, and measured with an accuracy of $0.1 \mathrm{mg}$. The content of insoluble substances was calculated from the mass differences $[6,16]$. 


\subsubsection{Determination of $H M F$ content (Winkler photometric method)}

The method is based on the reaction of 5hydroxymethylfurfural with barbituric acid and $p$ toluidine to give a compound whose absorption maximum is in the UV-Vis range at $550 \mathrm{~nm} \mathrm{[6,}$ 16].

\subsubsection{Determination of diastasis activity}

Determination of the diastatic activity of honey is done by a photometric method in which an insoluble, blue-dyed, cross-linked type of starch is used as the substrate. This is hydrolyzed by the enzyme, yielding blue water-soluble fragments, determined photometrically at $620 \mathrm{~nm}$. The absorbance of the solution is directly proportional to the diastatic activity of the sample $[6,16]$. One gram of honey sample was weighed in a $100 \mathrm{ml}$ volumetric flask and dissolved in acetate buffer solution (0.1 M, pH 5.2) and filled to the mark. The procedure was complete within $1 \mathrm{~h}$. Five milliliters of the solution was transferred to a test tube, which was placed in a water bath at $40{ }^{\circ} \mathrm{C}$. The blank was prepared by placing a $5.0 \mathrm{ml}$ aliquot of the acetate buffer in another test tube, which was treated exactly as the sample solution. The Phadebas tablets were added to both solutions using tweezers, and started measuring the time. A reagent mixer was used to stir the solutions until the tablets disintegrated (ca. $10 \mathrm{~s}$ ) and the mixture was returned to the water bath. The reaction was terminated after exactly $15 \mathrm{~min}$ by adding $1 \mathrm{ml}$ of sodium hydroxide solution $(0.5 \mathrm{M})$. The mixture was stirred again in the reagent mixer for approximately $5 \mathrm{~s}$. The solutions were immediately filtered using filter paper, and the absorbance was measured in $1 \mathrm{~cm}$ cuvettes at 620 $\mathrm{nm}$ using water as the reference. The absorbance of the blank was subtracted from that of the sample solution $\left(\Delta \mathrm{A}_{620}\right)[6,16]$.

The diastase activity is expressed as the diastase number (DN) in Schade units and is defined as follows: one diastase unit corresponds to the enzyme activity of $1 \mathrm{~g}$ of honey, which can hydrolyze $0.01 \mathrm{~g}$ of starch in $1 \mathrm{~h}$ at $40{ }^{\circ} \mathrm{C}$. Linear regression of $y$ (diastase number) against $\times\left(\Delta A_{620}\right)$ yielded the following relation:

$$
\mathrm{DN}=28.2 \times \Delta A_{620}+2.64
$$

where 28.2 and 2.64 are the slope and intercept, respectively, of the best straight line obtained by linear regression of $\Delta A_{620}$ ( $x$ axis) on DN ( $y$ axis).

\subsubsection{Determination of total phenols in honey}

Total phenolic compounds were determined with the use of Folin-Ciocalteu's reagent. Approximately five grams of honey was weighed and dissolved in an appropriate volume of water so that the concentration of honey was $0.1 \mathrm{~g}$ of honey $/ \mathrm{ml}$. The resulting solution was filtered (regenerated cellulose (RC) $0.45 \mu \mathrm{m}$ ), and the filtrate was used to determine the total phenolic content. FolinCiocalteu reagent $(2.5 \mathrm{ml}, 0.2 \mathrm{~mol} / \mathrm{l})$ was added to $500 \mu \mathrm{l}$ of the solution, and $2 \mathrm{ml}$ of $\mathrm{Na}_{2} \mathrm{CO}_{3}$ solution $(75 \mathrm{~g} / \mathrm{l})$ was added after $5 \mathrm{~min}$. All samples were incubated at room temperature in the dark for $2 \mathrm{~h}$, and then their absorbance was measured at 760 $\mathrm{nm}$. The blank contained methanol instead of honey. Gallic acid was used to construct the calibration curve [18]. The linearity coefficient was $0.9992\left(R^{2}\right)$.

\subsubsection{Qualitative analysis of phenolic compounds}

The honey sample (100 g), to which $100 \mu \mathrm{g}$ of dihydroquercetin was added as an internal standard, was diluted with $100 \mathrm{ml}$ of water and then extracted three times with $100 \mathrm{ml}$ of ethyl acetate [19]. The combined ethyl acetate solutions were evaporated to dryness, and the obtained extract was further used for liquid chromatographymass spectrometry (LC/MS) analysis. Honey extract samples $(10 \mathrm{mg})$ were diluted in $1 \mathrm{ml}$ of methanol, filtered $(0.45 \mu \mathrm{m} \mathrm{RC}$ filter), and analyzed on an Agilent Technologies 1200 series HPLC using Zorbax Eclipse Plus C18 $(150 \times 4.6$ $\mathrm{mm}$ i.d.; $1.8 \mu \mathrm{m}$ ) connected to a diode array detector (DAD) and Agilent Technologies 6210 Timeof-Flight LC/MS system equipped with an electrospray ionization source (ESI), as described in Gođevac et al. [20]. The mobile phase consisted of two solvents: solvent A (water/formic acid [99.5:0.5 v/v]) and solvent B (acetonitrile [100 $\mathrm{v} / \mathrm{v}])$. Phenolic compounds were eluted under the following conditions: $0.95 \mathrm{ml} \mathrm{min}{ }^{-1}$ flow rate, gradient program (0-20 min 5-16\% B, 20-28 min 16-40\% B, 28-40 min 40-90\% B, 40-45 min 90 $\% \mathrm{~B}, 45-46 \min 95-5 \% \mathrm{~B}, 46-51 \min 5 \% \mathrm{~B})$, followed by washing and reconditioning of the column. The UV spectra (scanning from 190-450 $\mathrm{nm})$ were recorded for all peaks. Triplicate analyses were performed for each sample. Mass spectra were acquired using an Agilent Technologies 6210 LC/ESI ToF MS System. The working parameters were as follows: capillary voltage, $4000 \mathrm{~V}$; fragmentor voltage, $140 \mathrm{~V}$; nebulizer pressure, $45 \mathrm{psig}$; drying gas, $12 \mathrm{l} / \mathrm{min}$; gas temperature, $350{ }^{\circ} \mathrm{C}$; 
mass range, $m / z$ 100-1500; negative ionization mode. Processing of data was done with MassHunter Workstation software.

The following standard substances were used for the identification and quantification of phenolic compounds: gallic acid, protocatechuic acid, $p$-hydroxybenzoic acid, chlorogenic acid, vanillic acid, caffeic acid, $p$-coumaric acid, ferulic acid, myricetin, luteolin, quercetin, apigenin, kaempferol, isorhamnetin, chrysin, pinocembrin and galangin. Dihydroquercetin was used as the internal standard.

The identification of separated honey phenols was based on the comparison of chromatographic data (retention times), UV spectra, and ESI MS spectra with authentic compounds and the available literature data [21], while quantification was performed through external calibration with the same compounds. The linearity range of the analytes, limit of detection (LOD), limit of quantification (LOQ), and recoveries for three concentration levels were determined.

\subsubsection{Statistical analysis}

All measurements were performed in triplicate, and the data were expressed as the mean \pm standard deviation (Excel 2016, Microsoft, Redmond, USA). Duncan's multiple range test was used to compare significant differences among the honey samples. Significant differences were statistically considered at the level of $p \leq 0.05$ [22]. The heat map is useful for visualizing numerical data because the individual values contained in the data matrix are represented by color. If combined with hierarchical classification, it becomes a useful exploratory statistical technique suitable for identifying patterns in grouping, both honey and quantified chemical components in them. The analytical goal is to group honey samples into clusters so that the samples within the same cluster are more similar to each other in terms of quantified physicochemical parameters than to samples from other clusters. This way of visualizing experimental data enables the discovery of sub-structures inherent in a given data set as well as the way in which the observed physicochemical parameters cause the grouping of honey samples. To avoid the influence of the unit of measurement on the results of grouping, all data were first standardized, i.e. reduced to zero average and unit dispersion. Euclidean distance was used as a measure of the similarity of honey samples, while the similarity of physicochemical parameters was quantified by Pearson's correlation coefficient. The first step in classification is to calculate the distance matrix. The grouping algorithm in the first step combines the samples with the smallest distance. The distance matrix is then recalculated according to the selected connection function. In this paper, Ward's linkage method, i.e. the method of the minimum sum of squares, was used. The input data were the contents of reducing sugars, sucrose, water, insoluble matter, free acids, HMF, minerals, total phenols, diastase activity, and electrical conductivity for the first model and the data from quantitative analysis of phenolic compounds for the second model. Math Works, Inc. MATLAB Version 2020a software was used to construct the heat map.

\section{RESULTS AND DISCUSSION}

The results of the physicochemical analysis are reported in Tab. 1. Designations B1-B11 and S1-S6 represent samples of acacia and sunflower honey, respectively. The reducing sugar content was between $67.0 \%$ (sample B9) and $80.6 \%$ (sample S3), while the content of sucrose ranged from 0.2 to $0.3 \%$, with the exception of sample B3, where the reducing sugar content was $0.8 \%$. The water content was between $14.5 \%$ (sample B3) and $19.8 \%$ (sample S4). The content of insoluble matter in most of the samples was in the range $0.02-0.03 \%$, only the sample S3 $(0.05 \%)$, samples S2, S4 and S5 (0.06\%), S6 (0.07\%) and sample S1 $(0.08 \%)$ had higher values. The free acid content ranged from $6.6 \mathrm{mEq} / \mathrm{kg}$ (sample B4) to $39.4 \mathrm{mEq} / \mathrm{kg}$ (sample S1). The HMF content of honey varied between $1.0 \mathrm{mg} / \mathrm{kg}$ (sample S1) and $20.8 \mathrm{mg} / \mathrm{kg}$ (sample B9). The diastase activity was the lowest in sample B2 (8.2 Schade units/g honey) and the highest in sample S4 (22.7 Schade units/g honey). The electrical conductivity was between $83.4 \mu \mathrm{S} / \mathrm{cm}$ (sample B2) and $359 \mu \mathrm{S} / \mathrm{cm}$ (sample $\mathrm{S} 1)$. The mineral matter content was the lowest in sample B3 $(0.04 \%)$ and the highest in sample S6 $(0.30 \%)$. In this research, the content of total phenolic compounds was also determined. The lowest content of total phenolic compounds was in sample S2 (37.84 mg GAE/100 g honey) and the highest was in sample B9 (142.61 mg GAE/100 g honey).

The tentative analysis of the samples demonstrated the presence of 93 phenolic compounds (Tab. S1, supplementary material), 19 of which were quantified (gallic acid, protocatechuic acid, $p$-hydroxybenzoic acid, chlorogenic acid, vanillic acid, caffeic acid, $p$-coumaric acid, ferulic acid, myricetin, luteolin, quercetin, abscisic acid, naringenin, apigenin, kaempferol, isorhamnetin, chrysin, galangin, and pinocembrin) (Tab. 2). 
The obtained results show that all tested samples meet the standards laid out in Council Regulation 2014/63/EU from 15 May 2014 [1]. There was a statistically significant difference in the results obtained with the tested honey for the content of water-insoluble substances and minerals, as well as the electrical conductivity.

The mean moisture content values were 16.9 $\pm 2.4 \%$ and $18.4 \pm 1.4 \%$ for acacia and sunflower honey, respectively. The obtained results are close to those previously reported by Sakač et al. [23] for acacia and sunflower honey and by Popek [24] and Isopescu et al. [25] for acacia honey. Sakač et al. [23] analyzed honey samples from the Autonomous Province of Vojvodina (Republic of Serbia), and they reported a moisture content of $16.6 \pm 1.82$
$\%$ for acacia and $17.8 \pm 1.55 \%$ for sunflower honey. In our study, the moisture content was the lowest for acacia honey, and this result is close to the results reported by Mădaş et al. [26]. Honey acidity is related to the presence of organic acids (formic, malic, citric, succinic, gluconic acids, etc.) [27] and some other compounds, such as lactones, esters, inorganic ions [3], phenolic compounds, vitamin $\mathrm{C}$, proteins, and other compounds, which can act as proton donors [23]. In our study, acacia honey had a lower mean value for acidity $(10.7 \pm$ $4.8 \mathrm{mEq} / \mathrm{kg}$ ) in comparation with sunflower honey acidity (mean value $28.6 \pm 10.8 \mathrm{mEq} / \mathrm{kg}$ ). The obtained mean value for the acidity of acacia honey is in accordance with the data given by Sakač et al. [23] and Isopescu et al. [25].

Table 1

Results of the physicochemical analyses and the data used for the statistical analysis

\begin{tabular}{|c|c|c|c|c|c|c|c|c|c|c|}
\hline Sample & $\begin{array}{c}\text { Reducing } \\
\text { sugar } \\
(\%)\end{array}$ & $\begin{array}{c}\text { Sucrose } \\
(\%)\end{array}$ & $\begin{array}{c}\text { Water } \\
(\%)\end{array}$ & $\begin{array}{c}\text { Insoluble } \\
\text { matter } \\
(\%)\end{array}$ & $\begin{array}{c}\text { Free } \\
\text { acids } \\
(\mathbf{m E q} / \mathbf{k g})\end{array}$ & $\begin{array}{c}\text { HMF } \\
(\mathrm{mg} / \mathrm{kg})\end{array}$ & $\begin{array}{l}\text { Diastase } \\
\text { activity } \\
\text { (IU) }\end{array}$ & $\begin{array}{c}\text { Electrical } \\
\text { conductivity } \\
(\mu \mathrm{S} / \mathrm{cm})\end{array}$ & $\begin{array}{c}\text { Mineral } \\
\text { composition } \\
(\%)\end{array}$ & $\begin{array}{c}\begin{array}{c}\text { Total } \\
\text { phenolic } \\
\text { (mg GAE/ }\end{array} \\
\text { 100 g honey) }\end{array}$ \\
\hline B1 & $67.5 \pm 0.5$ & $0.2 \pm 0.1$ & $17.1 \pm 0.7$ & $0.02 \pm 0.01$ & $14.5 \pm 1.2$ & $7.6 \pm 1.1$ & $12.1 \pm 0.3$ & $174.0 \pm 20.2$ & $0.15 \pm 0.02$ & $93.13 \pm 1.45$ \\
\hline B2 & $69.3 \pm 0.8$ & $0.3 \pm 0.1$ & $17.6 \pm 0.6$ & $0.02 \pm 0.00$ & $7.9 \pm 0.3$ & $4.6 \pm 0.3$ & $8.2 \pm 1.2$ & $83.4 \pm 12.4$ & $0.06 \pm 0.01$ & $58.17 \pm 2.91$ \\
\hline B3 & $69.4 \pm 0.5$ & $0.8 \pm 0.2$ & $14.5 \pm 0.2$ & $0.02 \pm 0.00$ & $8.4 \pm 0.7$ & $6.5 \pm 0.7$ & $8.3 \pm 0.9$ & $84.3 \pm 9.7$ & $0.04 \pm 0.01$ & $65.27 \pm 1.46$ \\
\hline B4 & $72.8 \pm 0.1$ & $0.3 \pm 0.0$ & $15.8 \pm 0.1$ & $0.03 \pm 0.01$ & $6.6 \pm 0.2$ & $15.0 \pm 0.9$ & $10.3 \pm 0.4$ & $92.0 \pm 13.9$ & $0.06 \pm 0.01$ & $77.53 \pm 1.41$ \\
\hline B5 & $79.2 \pm 0.4$ & $0.2 \pm 0.0$ & $18.4 \pm 0.9$ & $0.02 \pm 0.01$ & $12.2 \pm 0.1$ & $4.7 \pm 0.2$ & $11.1 \pm 0.1$ & $134.0 \pm 19.0$ & $0.08 \pm 0.01$ & $107.58 \pm 0.00$ \\
\hline B6 & $74.5 \pm 0.8$ & $0.2 \pm 0.1$ & $17.3 \pm 1.2$ & $0.03 \pm 0.01$ & $10.4 \pm 0.8$ & $5.0 \pm 0.2$ & $12.9 \pm 0.8$ & $99.7 \pm 10.8$ & $0.05 \pm 0.00$ & $79.71 \pm 1.47$ \\
\hline B7 & $75.9 \pm 0.3$ & $0.2 \pm 0.0$ & $17.1 \pm 1.0$ & $0.02 \pm 0.00$ & $11.9 \pm 0.2$ & $8.8 \pm 0.1$ & $12.1 \pm 0.2$ & $129.0 \pm 6.5$ & $0.06 \pm 0.01$ & $99.54 \pm 1.45$ \\
\hline B8 & $72.6 \pm 0.1$ & $0.2 \pm 0.0$ & $17.1 \pm 0.3$ & $0.03 \pm 0.00$ & $9.9 \pm 0.7$ & $16.6 \pm 0.4$ & $11.3 \pm 0.5$ & $96.8 \pm 4.1$ & $0.05 \pm 0.01$ & $87.85 \pm 1.45$ \\
\hline B9 & $67.0 \pm 0.9$ & $0.3 \pm 0.1$ & $16.0 \pm 0.3$ & $0.02 \pm 0.01$ & $15.5 \pm 0.3$ & $20.8 \pm 0.2$ & $20.0 \pm 0.3$ & $169.0 \pm 11.3$ & $0.10 \pm 0.02$ & $142.61 \pm 1.45$ \\
\hline B10 & $75.4 \pm 0.6$ & $0.2 \pm 0.1$ & $18.5 \pm 1.0$ & $0.02 \pm 0.01$ & $12.4 \pm 0.8$ & $7.2 \pm 0.9$ & $9.0 \pm 1.3$ & $141.0 \pm 10.0$ & $0.08 \pm 0.02$ & $110.07 \pm 1.41$ \\
\hline B11 & $74.4 \pm 0.6$ & $0.2 \pm 0.1$ & $16.1 \pm 0.7$ & $0.02 \pm 0.00$ & $8.4 \pm 1.2$ & $9.4 \pm 1.0$ & $9.1 \pm 0.9$ & $93.1 \pm 17.5$ & $0.05 \pm 0.02$ & $83.35 \pm 2.23$ \\
\hline S1 & $77.8 \pm 0.2$ & $0.2 \pm 0.0$ & $18.7 \pm 0.3$ & $0.08 \pm 0.02$ & $39.4 \pm 0.3$ & $1.0 \pm 0.0$ & $19.3 \pm 0.1$ & $359.0 \pm 22.7$ & $0.24 \pm 0.03$ & $53.99 \pm 1.49$ \\
\hline S2 & $76.4 \pm 1.0$ & $0.3 \pm 0.1$ & $17.4 \pm 0.6$ & $0.06 \pm 0.01$ & $28.4 \pm 0.8$ & $3.4 \pm 0.3$ & $20.5 \pm 0.2$ & $231.0 \pm 18.3$ & $0.14 \pm 0.02$ & $37.84 \pm 0.97$ \\
\hline $\mathbf{S 3}$ & $80.6 \pm 0.5$ & $0.2 \pm 0.0$ & $17.4 \pm 0.7$ & $0.05 \pm 0.01$ & $28.4 \pm 0.4$ & $4.8 \pm 0.1$ & $14.4 \pm 1.3$ & $238.0 \pm 15.1$ & $0.12 \pm 0.02$ & $44.05 \pm 0.74$ \\
\hline S4 & $75.2 \pm 1.1$ & $0.3 \pm 0.1$ & $19.8 \pm 0.2$ & $0.06 \pm 0.01$ & $27.1 \pm 0.9$ & $4.0 \pm 0.1$ & $22.7 \pm 0.1$ & $200.0 \pm 10.0$ & $0.12 \pm 0.02$ & $42.80 \pm 0.55$ \\
\hline S5 & $78.3 \pm 0.7$ & $0.2 \pm 0.1$ & $19.0 \pm 0.9$ & $0.06 \pm 0.02$ & $18.5 \pm 1.3$ & $4.9 \pm 0.3$ & $21.2 \pm 0.1$ & $191.0 \pm 13.3$ & $0.12 \pm 0.03$ & $25.45 \pm 0.06$ \\
\hline S6 & $73.9 \pm 0.4$ & $0.3 \pm 0.1$ & $18.2 \pm 1.1$ & $0.07 \pm 0.01$ & $29.7 \pm 0.4$ & $1.5 \pm 0.2$ & $21.2 \pm 0.5$ & $189.0 \pm 19.4$ & $0.30 \pm 0.01$ & $61.09 \pm 1.04$ \\
\hline & & & & $\mathrm{SD}, \mathrm{p} \leq 0$ & & & & & & \\
\hline
\end{tabular}

However, there are differences in the acidity of sunflower honey compared to the data reported by Sakač et al. [23]. The sunflower honey samples analyzed by the mentioned authors had a mean acidity value of $19.1 \pm 3.19 \mathrm{mEq} / \mathrm{kg}$, while in this study the mean value was $28.6 \pm 10.8 \mathrm{mEq} / \mathrm{kg}$. The acidity results of sunflower honey are still in agreement with the results obtained by Lazarević et al. [28], where the mean value of acidity was $27.16 \pm 7.1 \mathrm{mEq} / \mathrm{kg}$.

The decomposition of hexoses (glucose, fructose, etc.) during the Maillard reaction produces HMF [29]. The maximum level of HMF in honey $(40.00 \mathrm{mg} / \mathrm{kg})$ is defined in the Codex Alimentarius standard for honey [17]. Up to $10 \mathrm{mg} / \mathrm{kg}$ of HMF is naturally present in honey [30], while 
higher amounts of HMF in honey may be due to heating of the honey or its inadequate storage [31]. Three of the eleven acacia honey samples (B4, B8, and B9) had HMF content greater than $10 \mathrm{mg} / \mathrm{kg}$ (15.0, 16.6 and $20.8 \mathrm{mg} / \mathrm{kg}$, respectively), while the other analyzed samples had values up to 10 $\mathrm{mg} / \mathrm{kg}$. The results obtained for acacia and sunflower honey are similar to those previously reported by Sakač et al. [23] and Truzzi et al. [32].

The electrical conductivity of honey is directly correlated with the concentration of ions, acids, and proteins present in honey [31]. The results obtained for electrical conductivity for all types of honey in this study differed from the results reported by Lazarević et al. [28] and Sakač et al. [23], but the results obtained for acacia and sunflower honey are close to those previously reported by Truzzi et $a l$. [32] for Italian and European honey.

The mineral content of all honey samples varied between $0.05 \%$ and $0.47 \%$, with significant differences $(p \leq 0.05)$ between honey types. Sakač et al. [23] reported that the range of ash content was $0.05-0.11 \%$ for acacia honey and 0.08 $0.22 \%$ for sunflower honey, and the results obtained for acacia and sunflower honey in our study are comparable with the results from this author.

The measurement of water-insoluble matter is an important means of detecting honey impurities [17]. These impurities include wax, pollen, honeycomb, bees and filth particles [33]. The content of water-insoluble matter is related to the care of beekeepers when collecting and storing honey [34]. The results obtained for acacia honey are close to those previously reported by Matović et al. [35], Ciric et al. [36] and Vranić et al. [33], while there are differences in the results obtained for sunflower honey samples. Matović et al. [35] reported the content of water-insoluble matter in the range of $0.01-0.03 \%$ for sunflower honey, while in this study the content of insoluble matter was in the range of $0.06-0.08 \%$.

Diastase is a particularly important enzyme in honey; its role is to convert starch to short-chain sugars (glucose and fructose). Decreased diastase activity may be caused by heating or poor honey storage conditions [35]. The diastase activities were $12.6 \pm 8.7$ and $19.9 \pm 5.5$ for acacia and sunflower honey, respectively, and these results are in accordance with the results reported by Ciric et al. [36] for acacia honey. There were differences in the results for the sunflower honey. Matović et al. [35] reported higher values (32.12-45.59) for diastase activity obtained in this study (14.4-21.2).
However, the obtained results are in accordance with the results reported by Sari and Ayyildiz [37].

Sugars are the main compounds in honey. The most represented sugars are monosaccharides, and, in a small amount, sucrose (disaccharide) is present. The obtained results (mean values) for reducing sugars were $72.5 \pm 6.7 \%$ and $77.0 \pm 3.6$ $\%$ for acacia and sunflower honey, respectively. The results for acacia honey are in accordance with those reported by Popek [24] and Ciric et al. [36], while the value for sunflower honey is in accordance with the results reported by Hussien [38]. The sucrose content was in the range of $0.2-0.3 \%$ (except for sample B3) for all samples, and these results were different from the literature data.

Phenolic compounds are important components of honey, and they are responsible for various biological activities of honey. The mean values of total phenolic content were $91.35 \pm 51.26 \mathrm{mg}$ $\mathrm{GAE} / 100 \mathrm{~g}$ and $44.2 \pm 18.75 \mathrm{mg} \mathrm{GAE} / 100 \mathrm{~g}$ for acacia and sunflower honey, respectively. The value for acacia honey is higher than the values reported by Gül and Pehlivan [39] (51.91 $\pm 1.32 \mathrm{mg}$ GAE/100 g) and Cheung et al. [40] (74.10 \pm 7.72 $\mathrm{mg}$ GAE/100 g). The results obtained for sunflower honey are lower than those reported by Gül and Pehlivan [39] (77.64 $\pm 0.86 \mathrm{mg} \mathrm{GAE} / 100 \mathrm{~g})$.

The results of Kečkeš et al. [41], who analyzed the phenolic profiles of Serbian unifloral honeys, for gallic acid in acacia honey agree with the results from this study; however, there are differences in the concentration range for sunflower honey. While Kečkeš et al. [41] reported a concentration range for gallic acid between 0.0 and 14.5 $\mu \mathrm{g} / 100 \mathrm{~g}$ in sunflower honey, the concentration of gallic acid was less than the LOQ in this study. The obtained concentration ranges for caffeic, $p$ coumaric, and protocatechuic acid were 4 to 11 times higher than the concentration ranges reported by Kečkeš et al. [41]. Another deviation in the obtained results in comparison with the results reported by Kečkeš et al. [41] was observed with abscisic acid. The presence of this acid was not detected in most samples (exceptions were samples B4, B6, B8 and B10), while in the study by Kečkeš et al. [41] the concentration ranges of abscisic acid were between 42 and $139 \mu \mathrm{g} / 100 \mathrm{~g}$ and between 3 and $40 \mu \mathrm{g} / 100 \mathrm{~g}$ in acacia and sunflower honey samples, respectively. Kečkeš et al. [41] quantified three flavones (apigenin, luteolin and chrysin), four flavanols (myricetin, quercetin, kaempferol and galangin), and one flavanone (pinocembrin), which were also quantified in this study. 
Table 2

Results of the quantitative analysis of phenolic acids and flavonoids in honey samples

\begin{tabular}{|c|c|c|c|c|c|c|c|c|c|c|c|c|c|c|c|c|c|c|}
\hline \multirow{2}{*}{ Compound } & \multicolumn{10}{|c|}{ Acacia honey ( $\mu \mathrm{g} / \mathbf{1 0 0} \mathrm{g}$ honey) } & \multicolumn{8}{|c|}{ Sunflower honey ( $\mu \mathrm{g} / \mathbf{1 0 0} \mathrm{g}$ honey) } \\
\hline & $\bar{\theta}$ & $\tilde{\oplus}$ & $\mathscr{\theta}$ & \pm & $\Leftrightarrow$ & ๑̊ & $\hat{\oplus}$ & 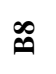 & $\hat{\theta}$ & $\stackrel{\theta}{*}$ & $\bar{\theta}$ & $\bar{n}$ & $\tilde{n}$ & $\theta$ & 苾 & $n$ & i & \\
\hline Caffeic acid & 苍 & 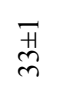 & $\underset{\infty}{\vec{D}}$ & $\underset{\substack{+\infty}}{+\infty}$ & $\begin{array}{l}0 \\
+1 \\
0 \\
0\end{array}$ & त्र & $\underset{\infty}{\pi}$ & $\frac{\pi}{m}$ & $\begin{array}{l}\text { तु } \\
\text { ปे }\end{array}$ & 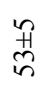 & 菅 & $\begin{array}{l}\text { Iै } \\
\ddot{\alpha}\end{array}$ & 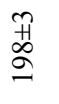 & 站 & 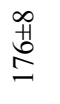 & त्ञ & $\begin{array}{l}\frac{\pi}{4} \\
\substack{4 \\
0}\end{array}$ & \\
\hline $\begin{array}{l}p \text {-Coumaric } \\
\text { acid }\end{array}$ & $\stackrel{n}{m}$ & $\stackrel{\#}{m}$ & ت्H & $\frac{\pi}{N}$ & 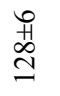 & 望 & 苦 & 莍 & $\underset{n}{\stackrel{n}{N}}$ & 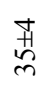 & 贲 & $\begin{array}{l}n \\
\stackrel{n}{N} \\
\infty\end{array}$ & 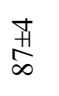 & 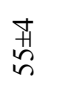 & 華 & तै & $\frac{2}{2}$ & \\
\hline Ferulic acid & 芳 & 菖 & Iี & $\stackrel{\text { त }}{=}$ & $\stackrel{n}{n}$ & 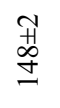 & 夰 & 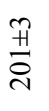 & $\begin{array}{l}\stackrel{0}{0} \\
\text { i } \\
\sim\end{array}$ & 葛 & $\frac{\pi}{N}$ & $\underset{8}{g}$ & $\begin{array}{l}8 \\
0 \\
1\end{array}$ & $\begin{array}{l}g \\
\text { g } \\
v\end{array}$ & $\underset{8}{g}$ & $\begin{array}{l}\text { g } \\
\text { v }\end{array}$ & $\begin{array}{l}\text { g } \\
\text { v }\end{array}$ & \\
\hline $\begin{array}{l}\text { Chlorogenic } \\
\text { acid }\end{array}$ & ô & ô & oิ & oิ & oิ & 命 & $\begin{array}{l}\text { ô } \\
\text { v }\end{array}$ & ô & $\begin{array}{l}\text { ô } \\
\text { v }\end{array}$ & $\begin{array}{l}\text { ô } \\
\text { v }\end{array}$ & $\begin{array}{l}\text { ô } \\
\text { v }\end{array}$ & 苦 & 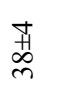 & $\begin{array}{l}n \\
\begin{array}{l}n \\
\infty \\
\infty \\
\infty\end{array}\end{array}$ & $\begin{array}{l}0 \\
0 \\
0\end{array}$ & 융 & $\stackrel{\text { \# }}{=}$ & \\
\hline $\begin{array}{l}\text { Protocatehuic } \\
\text { acid }\end{array}$ & $\underset{\substack{0 \\
\infty}}{\sim}$ & 苦 & $\vec{H}$ & 槅 & 茪 & 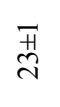 & 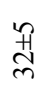 & $\begin{array}{l}\vec{H} \\
m\end{array}$ & $\begin{array}{l}0 \\
\infty \\
\infty \\
m\end{array}$ & $\begin{array}{l}\text { 苦 } \\
\text { a }\end{array}$ & 萜 & 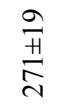 & $\begin{array}{l}\infty \\
\stackrel{0}{2} \\
2\end{array}$ & $\begin{array}{l}\vec{T} \\
\stackrel{\mathbb{I}}{\Xi}\end{array}$ & $\frac{\pi}{H}$ & 苦 & 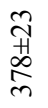 & \\
\hline $\begin{array}{l}\text { 2- Hydroxyben- } \\
\text { zoic acid }\end{array}$ & 贲 & oิ & ồ & Oิ & oิ & Oิ & $\begin{array}{l}\text { ô } \\
\text { v }\end{array}$ & $\begin{array}{l}\hat{0} \\
\text { จ } \\
\text { v }\end{array}$ & $\begin{array}{l}\hat{\text { ô }} \\
\text { v }\end{array}$ & $\begin{array}{l}\text { ô } \\
\text { v }\end{array}$ & ô & 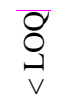 & $\begin{array}{l}\text { Og } \\
\stackrel{1}{v}\end{array}$ & $\begin{array}{c}\text { Og } \\
\stackrel{9}{v}\end{array}$ & 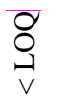 & 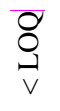 & $\begin{array}{l}\text { g } \\
\text { g } \\
\text { v }\end{array}$ & \\
\hline $\begin{array}{l}\text { 4- } \\
\text { Hydroxybenzoic } \\
\text { acid }\end{array}$ & 菅 & $\frac{\pi}{\infty}$ & $\frac{\pi}{\Rightarrow}$ & $\underset{\infty}{\stackrel{9}{H}}$ & 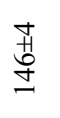 & $\underset{n}{\text { 营 }}$ & 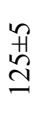 & 芩 & 袋 & 竞 & $\begin{array}{l}\infty \\
0 \\
0 \\
0\end{array}$ & $\begin{array}{l}\text { त } \\
\text { त̂ } \\
\text { ते }\end{array}$ & 䒪 & $\begin{array}{l}\text { in } \\
\text { ते } \\
n\end{array}$ & 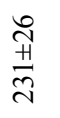 & 芰 & 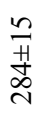 & \\
\hline Vanillic acid & oิ & oิ & Oิ & Oิ & Oิ & ָิ & $\begin{array}{l}\text { oิ } \\
\text { v }\end{array}$ & 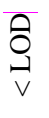 & ô & $\begin{array}{l}\hat{\text { ô }} \\
\text { v }\end{array}$ & $\begin{array}{l}\hat{\text { ô }} \\
\text { v }\end{array}$ & त्ञ & 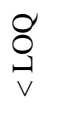 & 袋 & $\underset{8}{\stackrel{g}{9}}$ & 鬲 & $\underset{\substack{\text { g } \\
\text { v }}}{ }$ & \\
\hline Quercetin & $\frac{H}{m}$ & $\stackrel{\text { Iै }}{\text { m }}$ & तै & 艼 & 䓀 & 莴 & 营 & 茾 & $\stackrel{\nexists}{\#}$ & 푱 & 装 & 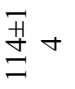 & 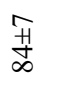 & $\begin{array}{l}\text { \# } \\
\text { م }\end{array}$ & त्र & $\stackrel{n}{\stackrel{n}{*}}$ & $\begin{array}{l}\text { 苦 } \\
\text { n }\end{array}$ & \\
\hline Kaempferol & तै & $\underset{n}{n}$ & 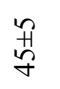 & 落 & $\begin{array}{l}\stackrel{+}{H} \\
\stackrel{+}{0}\end{array}$ & 幂 & तै & $\begin{array}{l}\text { 苦 } \\
\text { o }\end{array}$ & 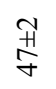 & 苦 & $\begin{array}{l}\text { N } \\
\text { in }\end{array}$ & 苦 & 용 & 융 & $\frac{+}{r}$ & 蒡 & 吾 & \\
\hline Naringenin & O্] & 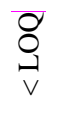 & $\underset{8}{O}$ & 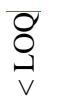 & 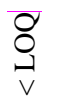 & $\underset{\substack{g \\
\mathrm{~g}}}{\mathrm{~g}}$ & $\frac{g}{\mathrm{~g}}$ & $\begin{array}{l}\text { g } \\
\text { g } \\
\text { (n) }\end{array}$ & $\underset{\mathrm{g}}{\mathrm{g}}$ & $\frac{g}{2}$ & $\begin{array}{l}\text { g } \\
\text { v }\end{array}$ & 苦 & $\underset{\substack{0 \\
\mathrm{~g}}}{\mathrm{~g}}$ & $\frac{\pi}{+}$ & त्र & $\begin{array}{l}0 \\
+ \\
\infty\end{array}$ & $\begin{array}{l}\frac{\pi}{4} \\
\text { in }\end{array}$ & \\
\hline Apigenin & $\begin{array}{l}n \\
\text { m } \\
m\end{array}$ & ग़ & $\begin{array}{l}\infty \\
\stackrel{+}{N} \\
=\end{array}$ & 풍 & $\frac{\pi}{\pi}$ & 팡 & 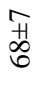 & $\begin{array}{l}\infty \\
\text { 苍 } \\
\text { n. }\end{array}$ & 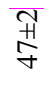 & $\begin{array}{l}\text { त् } \\
\text { ते }\end{array}$ & $\begin{array}{l}\text { त } \\
\text { m } \\
m\end{array}$ & $\frac{\pi}{\Rightarrow}$ & 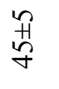 & 菖 & 芩 & $\underset{\mathscr{f}}{\mathscr{f}}$ & 菅 & 窇 \\
\hline Isohramnetin & T্ & $\frac{\pi}{6}$ & गे & 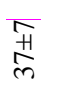 & $\frac{\bar{\theta}}{\underline{m}}$ & $\stackrel{\text { In }}{\text { भ }}$ & 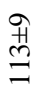 & $\begin{array}{l}\frac{\pi}{4} \\
\text { b }\end{array}$ & $\begin{array}{l}\text { पू } \\
\text { ूू }\end{array}$ & 莫 & त्र & 袋 & 芩 & 苦 & 迸 & 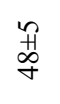 & त्र & 总 \\
\hline Chrysin & 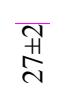 & त्ञ & 팜 & $\bar{\theta}$ & त्ञ & 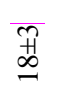 & $\frac{\pi}{6}$ & 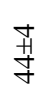 & 吾 & 覂 & 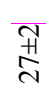 & 贲 & त्मे & 苦 & $\begin{array}{l}0 \\
\dddot{1} \\
2\end{array}$ & $\begin{array}{l}\frac{\pi}{1} \\
\stackrel{\infty}{\sim}\end{array}$ & $\begin{array}{l}\frac{\pi}{4} \\
\frac{1}{2}\end{array}$ & 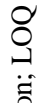 \\
\hline Pinocembrin & $\begin{array}{l}\tilde{n} \\
\text { ते } \\
\text { तु }\end{array}$ & $\frac{\bar{Z}}{\frac{\mathrm{H}}{\mathrm{I}}}$ & $\begin{array}{l}\text { 플 } \\
\text { ㅁ }\end{array}$ & 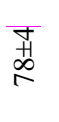 & $\begin{array}{l}n \\
0 \\
0 \\
0\end{array}$ & $\begin{array}{l}0 \\
\text { स } \\
\text { } \\
=\end{array}$ & $\begin{array}{l}\text { त्र } \\
\text { त̂ } \\
\text { ñ }\end{array}$ & $\begin{array}{l}\infty \\
\stackrel{\infty}{+} \\
-\infty\end{array}$ & $\overline{\vec{\nabla}}$ & $\begin{array}{l}\text { मे } \\
\stackrel{0}{=}\end{array}$ & $\begin{array}{l}\bar{\pi} \\
\text { ते }\end{array}$ & $\stackrel{\stackrel{n}{*}}{=}$ & $\underset{\substack{0\\
}}{+}$ & 帒 & $\begin{array}{l}0 \\
\infty \\
\infty \\
-1\end{array}$ & $\frac{n}{\vec{n}}$ & $\begin{array}{l}\infty \\
0 \\
\infty \\
\infty \\
-1\end{array}$ & 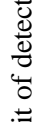 \\
\hline Galangin & 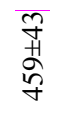 & $\begin{array}{l}\text { ते } \\
\text { त } \\
\end{array}$ & 鯎 & $\begin{array}{l}\overline{\vec{H}} \\
\stackrel{\bar{E}}{\Xi}\end{array}$ & 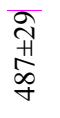 & $\begin{array}{l}\text { त } \\
\text { H্ } \\
\text { 品 }\end{array}$ & $\underset{m}{\stackrel{7}{*}}$ & $\begin{array}{l}\bar{\nabla} \\
\text { 苛 }\end{array}$ & $\begin{array}{l}\text { त } \\
\text { 苟 } \\
\text { d }\end{array}$ & $\begin{array}{l}\begin{array}{l}+ \\
+ \\
\infty\end{array} \\
\end{array}$ & $\begin{array}{l}\overline{\widetilde{T}} \\
\text { 合 }\end{array}$ & $\begin{array}{l}\text { 苦 } \\
\text { O }\end{array}$ & $\begin{array}{l}\text { OH } \\
\text { Oे } \\
\text { I }\end{array}$ & $\begin{array}{l}0 \\
\text { I1 } \\
\infty \\
\end{array}$ & 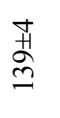 & $\begin{array}{l}0 \\
\text { İ } \\
0\end{array}$ & 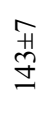 & о \\
\hline
\end{tabular}




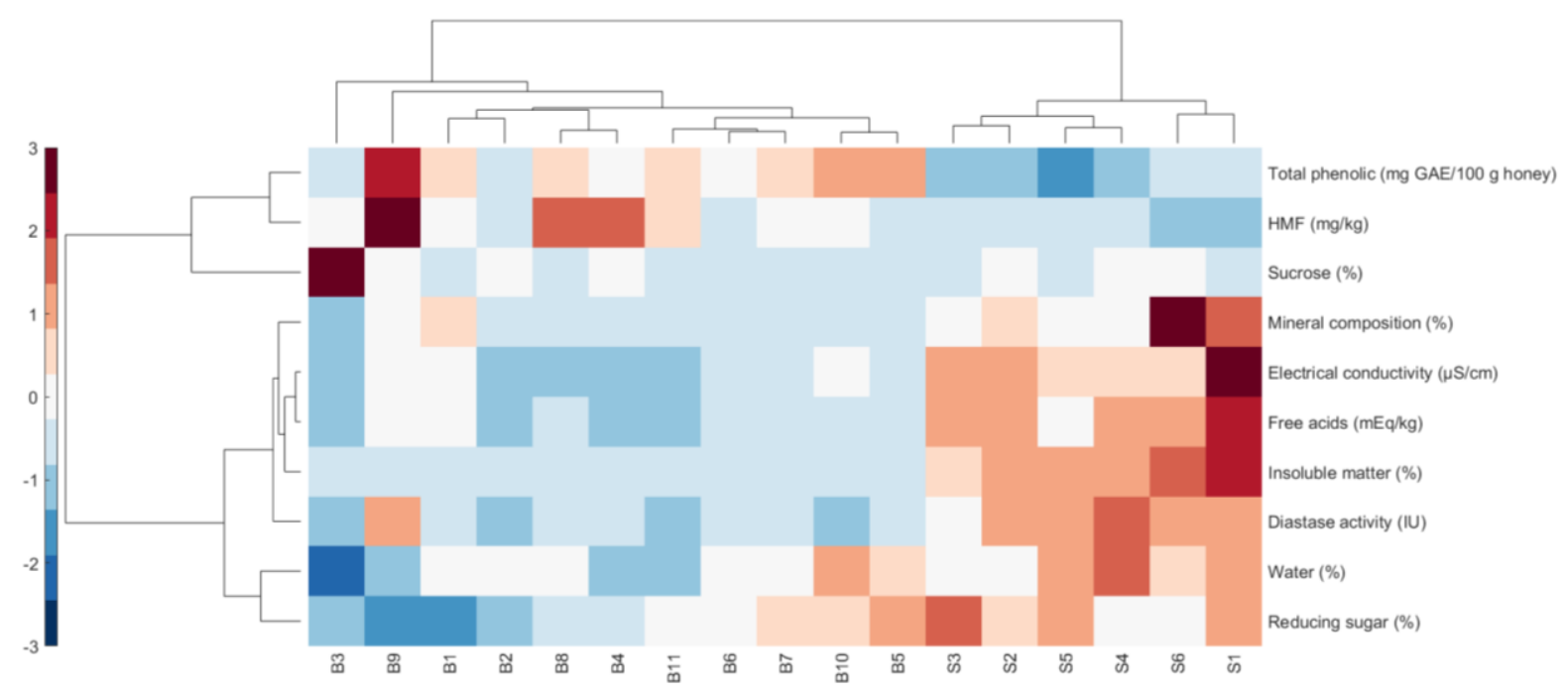

Fig. 2. Z-score hierarchical clustering heat map visualization. The levels of physicochemical parameters are different in acacia honey compared to sunflower honey. The colors represent scaled expression values, with blue for the low level physicochemical parameters and red for the high level physicochemical parameters.

The concentration of myricetin was less limit of quantification (LOQ) or limit of detection (LOD) in all samples in both studies, but there were significant differences in the concentration range for quercetin. In our study, the obtained concentration range was several times higher than in previous research [41]. There were also differences for other quantified compounds compared to the results presented by Kečkeš et al. [41].

The content of chlorogenic acid was in accordance with results reported by Sergiel et al. [42] and Cheung et al. [40]. The concentration of vanillic acid was less than the LOD for acacia honey, and these results are close to those reported by Cheung et al. [40]. The concentrations of $p$ hydroxybenzoic, vanillic and chlorogenic acids in sunflower honey were lower than those previously described by Pauliuc et al. [43]. Ferulic acid concentrations were higher than the concentration reported by Sergiel et al. [42] for acacia honey samples. The luteolin concentration was less than the LOD in the analyzed samples, and these results are in accordance with previous studies [42, 43]. However, the concentrations of chrysin, kaempferol, and pinocembrin differed from those reported by Sergiel et al. [42], Cheung et al. [40] and Pauliuc et al. [43]. These differences may be explained by the different geographical origins and could possibly be used for the geographical classification of honey [40].

The data obtained by the physicochemical analysis of honey samples were used for statistical processing to determine a simple, fast, and inexpensive method for evaluating the origin and clas- sification of honey. The data used for statistical processing were the contents of reducing sugars, sucrose, water, insoluble matter, free acids, HMF, minerals and total phenols, as well as the diastase activity and electrical conductivity. As a result of this analysis, a clear separation of samples by type of honey was obtained into two groups, one for acacia and one for sunflower honey samples (Fig. 2). The dendrogram above the heat map shows clear discrimination against acacia and sunflower honeys. In sunflower honey, almost all physicochemical parameters, except for HMF, sucrose and total phenolic content, have high, above-average values compared to acacia honey.

The composition of phenolic compounds has been reported in the literature as a possible parameter for the classification of monofloral honey using multivariate analysis of these data [11-15]. The input data used for this honey analysis did not give good separation of the honey into the groups. This may be due to the extremely low percentage of quantified phenolic compounds, and it should be verified if there was indeed a possibility of grouping honey based on the phenolic profile only after all the phenolic components were quantified.

\section{CONCLUSION}

In this study, we showed that the results obtained by standard laboratory analyses used for routine verification of honey have proven to be good and reliable inputs for multivariate analysis, which can verify the authenticity of the test sample and its monofloral affiliation. The obtained results 
could be widely applicable for the detection of fake honey, i.e. honey with a false declaration without additional financial cost. Laboratories that control the physicochemical parameters of honey only need some of the multivariate analysis software and databases created from the data obtained for monofloral honey. This would significantly reduce, if not prevent, the presence of fake honey in market.

Acknowledgements. This research was supported by the Ministry of Education, Science and Technological Development of the Republic of Serbia (grant nos. 172053 and contract numbers: 451-03-68/2020-14/200168 and 451-0368/2020-14-200026).

\section{REFERENCES}

[1] Council Directive 2001/110/EC of 20 December 2001 relating to honey, OJ L10, 47-52 (2002).

[2] A. S. Alqarni, A. A. Owayss, A. A. Mahmoud, M. A. Hannan, Mineral content and physical properties of local and imported honeys in Saudi Arabia, J. Saudi Chem. Soc. 18, 618-625 (2014).

DOI: https://doi.org/10.1016/j.jscs.2012.11.009

[3] P. M. da Silva, C. Gauche, L. V. Gonzaga, A. C. O. Costa, R. Fett, Honey: Chemical composition, stability and authenticity, Food Chem. 196, 309-323 (2016). DOI: https://doi.org/10.1016/j.foodchem.2015.09.051

[4] E. Schievano, C. Finotello, J. Uddin, S. Mammi, L. Piana, Objective definition of monofloral and polyfloral honeys based on NMR metabolomic profiling, J. Agric. Food Chem. 64, 3645-3652 (2016).

DOI: https://doi.org/10.1021/acs.jafc.6b00619

[5] O. L. Persano, R. Piro, Main European unifloral honeys: Descriptive sheets, Apidologie 35, 38-81 (2004). DOI: https://doi.org/10.1051/apido:2004049

[6] S. Bogdanov, Harmonised Methods of the International Honey Commission. International Honey Commission, 2009. Retrieved from http://www.ihc-platform.net/ ihcmethods2009.pdf

[7] A. Meda, C. E. Lamien, M. Romito, J. Milogo, O. G. Nacoulma, Determination of the total phenolic, flavonoid and proline contents in Burkina Fasan honey, as well at their radical scavenging activity, Food Chem. 91, 571-577 (2005).

DOI: https://doi.org/10.1016/j.foodchem.2004.10.006

[8] S. Ouchemoukh, H. Louaileche, P. Schweitzer, Physicochemical characteristics and pollen spectrum of some Algerian honeys, Food Control 18, 52-58 (2007). DOI: https://doi.org/10.1016/j.foodcont.2005.08.007

[9] D. Mariniova, F. Ribarova, M. Atanassova, Total phenolics and total flavonoids in Bulgarian fruits and vegetables, J. Chem. Technol. Metall. 40, 255-260 (2005).

[10] J. Bertoncelj, U. Doberšek, M. Jamnik, T. Golob, Evaluation of the phenolic content, antioxidant activity and colour of Slovenian honey, Food Chem. 105, 822828, (2007).

DOI: https://doi.org/10.1016/j.foodchem.2007.01.060
[11] M. J. Amiot, S. Aubert, M. Gonnet, M. Tacchini, Les composés phénoliques des miels: Étude préliminaire sur l'identification et la quantification par familles, Apidologie 20, 115-125 (1989). DOI: https://doi.org/10.1051/apido:19890202

[12] F. Ferreres, P. Andrade, M. I. Gil, F. A. TomásBarberán, Floral nectar phenolics as biochemical markers for the botanical origin of heather honey, $Z$. Lebensm. Unters. Forsch. 202, 40-44 (1996). DOI: https://doi.org/10.1007/BF01229682

[13] F. Ferreres, P. Andrade, F. A. Tomás-Barberán, Flavonoids from Portuguese heather honey, Z. Lebensm. Unters. Forsch. 199, 32-37 (1994). DOI: https://doi.org/10.1007/BF01192949

[14] P. Andrade, F. Ferreres, M. T. Amaral, Analysis of honey phenolic acids by HPLC, its application to honey botanical characterization, J. Liq. Chromatogr. Relat. Technol. 20, 2281-2288 (1997). DOI: https://doi.org/10.1080/10826079708006563

[15] P. Andrade, F. Ferreres, M. I. Gil, F. A. TomásBarberán, Determination of phenolic compounds in honeys with different floral origin by capillary zone electrophoresis, Food Chem. 60, 79-84 (1997). DOI: https://doi.org/10.1016/S0308-8146(96)00313-5

[16] Regulations on the quality of honey and other bee products, Službeni glasnik RS 101 (2015).

[17] Codex Alimentarius standard for honey 12-1981. Revised Codex standard for honey, Codex Alimentarius, 11, 1-8 (2019).

[18] V. L. Singleton, R. Orthofer, R. M. Lamuela-Raventos, Analysis of total phenols and other oxidation substrates and antioxidants by means of Folin-Ciocalteu reagent, Meth. Enzymol. 299, 152-178 (1999). DOI: https://doi.org/10.1016/S0076-6879(99)99017-1

[19] A. V. Tsiapara, M. Jaakkola, I. Chinou, K. Graikou, T. Tolonen, V. Virtanen, P. Moutsatsou, Bioactivity of Greek honey extracts on breast cancer (MCF-7), prostate cancer (PC-3) and endometrial cancer (Ishikawa) cells: Profile analysis of extracts, Food Chem. 116, 702-708 (2009). DOI: https://doi.org/10.1016/j.foodchem.2009.03.024

[20] D. Gođevac, V.Tešević, M. Veličković, Lj. Vujisić, V. Vajs, S. Milosavljević, Polyphenolic compounds in seeds from some grape cultivars grown in Serbia, $J$. Serb. Chem. Soc. 75, 1641-1652 (2010). DOI: https://doi.org/10.2298/JSC100519131G

[21] G. Lori, L. Cecchi, N. Mulinacci, F. Melani, A. Caselli, P. Cirri, L. Pazzagli, S. Luti, L. Mazzoli, P. Paoli, Honey extracts inhibit PTP1B, upregulate insulin receptor expression, and enhance glucose uptake in human HepG2 cells, Biomed. Pharmacother. 113, 108752 (2019). DOI: https://doi.org/10.1016/j.biopha.2019.108752

[22] M. J. Greenacre, Biplots in Practice, Foundación BBVA, Bilbao, 2010.

[23] M. B. Sakač, P. T. Jovanov, A. Z. Marić, L. L. Pezo, Ž. S. Kevrešan, A. R. Novaković, N. M. Nedeljković, Physicochemical properties and mineral content of honey samples from Vojvodina (Republic of Serbia), Food Chem. 276, 15-21 (2019). DOI: https://doi.org/10.1016/j.foodchem.2018.09.149

[24] S. Popek, A procedure to identify a honey type, Food Chem. 79, 401-406 (2002). DOI: https://doi.org/10.1016/S0308-8146(02)00391-6 
[25] R. D. Isopescu, A. M. Josceanu, T. Colta, R. Spulber, Romanian Honey: Characterization and Classification. In: Honey Analysis, V. De Alencar Arnaut De Toledo (Ed), InTechOpen, 2017.

DOI: https://doi.org/10.5772/66321, Available from: https://www.intechopen.com/books/honey-analysis/romanian-honey-characterization-and-classification

[26] N. M. Mădaş, L. A. Mărghitaş, D. S. Dezmirean, V. Bonta, O. Bobiş, M.-L. Fauconnier, F. Francis, E. Haubruge, K. B. Nguyen, Volatile profile and physicochemical analysis of acacia honey for geographical origin and nutritional value determination, Foods 8, 445 (2019). DOI: https://doi.org/10.3390/foods 8100445

[27] F. Tezcan, S. Kolayli, H. Sahin, E. Ulusoy, F. B. Erim, Evaluation of organic acid, saccharide composition and antioxidant properties of some authentic Turkish honeys, J. Food Nutr. Res. 50, 33-40, (2011).

[28] K. B. Lazarević, F. Andrić, J. Trifković, Ž. Tešić, D. Milojković-Opsenica, Characterisation of Serbian unifloral honeys according to their physicochemical parameters, Food Chem. 132, 2060-2064 (2012). DOI: https://doi.org/10.1016/j.foodchem.2011.12.048

[29] A. Ramírez-Jiménez, B. García-Villanova, E. GuerraHernández, Effect of toasting time on the browning of sliced bread: Browning of sliced bread, J. Sci. Food Agric. 81, 513-518 (2001).

DOI: https://doi.org/10.1002/jsfa.840

[30] A. S. Alqarni, A. A. Owayss, A. A. Mahmoud, Physicochemical characteristics, total phenols and pigments of national and international honeys in Saudi Arabia, Arab. J. Chem. 9, 114-120 (2016).

DOI: https://doi.org/10.1016/j.arabjc.2012.11.013

[31] Y. Yücel, P. Sultanoğlu, Characterization of honeys from Hatay Region by their physicochemical properties combined with chemometrics, Food Biosci. 1, 16-25 (2013). DOI: https://doi.org/10.1016/j.fbio.2013.02.001

[32] C. Truzzi, S. Illuminati, A. Annibaldi, C. Finale, M. Rossetti, G. Scarponi, Physicochemical properties of honey from marche, central italy: classification of unifloral and multifloral honeys by multivariate analysis, Nat. Prod. Commun. 9, 1934578X1400901 (2014). DOI: https://doi.org/10.1177/1934578X1400901117

[33] D. Vranic, R. Petronijevic, V. Koricanac, J. Djinovic Stojanovic, S. Lilic, B., Borovic, M. Lukic, Evaluation of Serbian black locust honey quality parameters as a contribution to confirmation of its botanical origin, IOP Conf. Ser.: Earth Environ. Sci. 333, 012113 (2019). DOI: https://doi.org/10.1088/1755-1315/333/1/012113
[34] T. L. Mesele, Review on physico-chemical properties of honey in Eastern Africa, J. Apic. Res. 1-13 (2020). DOI: https://doi.org/10.1080/00218839.2020.1754566

[35] K. Matović, J. Ćirić, V. Kaljević, N. Nedić, G. Jevtić, N. Vasković, M. Ž. Baltić, Physicochemical parameters and microbiological status of honey produced in an urban environment in Serbia, Environ. Sci. Pollut. Res. Int. 25, 14148-14157 (2018). DOI: https://doi.org/10.1007/s11356-018-1659-1

[36] J. Ciric, D. Sando, D. Spiric, J. Janjic, M. Boskovic, M. Glisic, M. Z. Baltic, Characterisation of Bosnia and Herzegovina honeys according to their physico-chemical properties during 2016-2017, Meat Technology 59, 4653 (2018).

DOI: https://doi.org/10.18485/meattech.2018.59.1.6

[37] E. Sari, N. Ayyildiz, Biological activities and some physicochemical properties of sunflower honeys collected from the Thrace region of Turkey, Pak. J. Biol. Sci. 15, 1102-1110 (2012).

DOI: https://doi.org/10.3923/pjbs.2012.1102.1110

[38] H. Y. A. E. Hussien, Physicochemical Properties of Honey from Different Floral Sources [MSc Thesis], Faculty of Agriculture, University of Khartoum, 2007.

[39] A. Gül, T. Pehlivan, Antioxidant activities of some monofloral honey types produced across Turkey, Saudi J. Biol. Sci. 25, 1056-1065 (2018). DOI: https://doi.org/10.1016/j.sjbs.2018.02.011

[40] Y. Cheung, M. Meenu, X. Yu, B. Xu, Phenolic acids and flavonoids profiles of commercial honey from different floral sources and geographic sources, Int. J. Food Prop. 22, 290-308 (2019). DOI: https://doi.org/10.1080/10942912.2019.1579835

[41] S. Kečkeš, U. Gašić, T. Ć. Veličković, D. MilojkovićOpsenica, M. Natić, Ž. Tešić, The determination of phenolic profiles of Serbian unifloral honeys using ultrahigh-performance liquid chromatography/high resolution accurate mass spectrometry, Food Chem. 138, 32-40 (2013).

DOI: https://doi.org/10.1016/j.foodchem.2012.10.025

[42] I. Sergiel, P. Pohl, M. Biesaga, Characterisation of honeys according to their content of phenolic compounds using high performance liquid chromatography/tandem mass spectrometry, Food Chem. 145, 404-408 (2014).

DOI: https://doi.org/10.1016/j.foodchem.2013.08.068

[43] D. Pauliuc, F. Dranca, M. Oroian, Antioxidant activity, total phenolic content, individual phenolics and physicochemical parameters suitability for Romanian honey authentication, Foods, 9 (3), 300 (2020). 
